\title{
Correction to: Improvement of summer precipitation simulation by correcting biases of spring soil moisture in the seasonal frozen-thawing zone over the Northern Hemisphere
}

\author{
Kechen $\mathrm{Li}^{1}$ · Feimin Zhang ${ }^{1} \cdot$ Kai Yang $^{1} \cdot$ Jiali Shen ${ }^{1} \cdot$ Chenghai Wang $^{1}$ (D)
}

Published online: 27 December 2021

(c) The Author(s) 2021

\section{Correction to: Climate Dynamics \\ https://doi.org/10.1007/s00382-021-06032-z}

The article "Improvement of summer precipitation simulation by correcting biases of spring soil moisture in the seasonal frozen-thawing zone over the Northern Hemisphere", written by Kechen Li, Feimin Zhang, Kai Yang, Jiali Shen, Chenghai Wang was originally published electronically on the publisher's internet portal on 16 May 2019 without open access. With the author(s)' decision to opt for Open Choice the copyright of the article changed on 1 November 2021 to (c) The Author(s) 2021 and the article is forthwith distributed under a Creative Commons Attribution 4.0 International License, which permits use, sharing, adaptation, distribution and reproduction in any medium or format, as long as you give appropriate credit to the original author(s) and the source, provide a link to the Creative Commons licence, and indicate if changes were made. The images or other third party material in this article are included in the article's Creative Commons licence, unless indicated otherwise in a credit line to the material. If material is not included in the article's Creative Commons licence and your intended use is not permitted by statutory regulation or exceeds the permitted use, you will need to obtain permission directly from the copyright holder. To view a copy of this licence, visit http://creativecommons.org/licenses/ by/4.0. Open access funding enabled and organized by Projekt DEAL.

The original article was corrected.

Open Access This article is licensed under a Creative Commons Attribution 4.0 International License, which permits use, sharing, adaptation, distribution and reproduction in any medium or format, as long as you give appropriate credit to the original author(s) and the source, provide a link to the Creative Commons licence, and indicate if changes were made. The images or other third party material in this article are included in the article's Creative Commons licence, unless indicated otherwise in a credit line to the material. If material is not included in the article's Creative Commons licence and your intended use is not permitted by statutory regulation or exceeds the permitted use, you will need to obtain permission directly from the copyright holder. To view a copy of this licence, visit http://creativecommons.org/licenses/by/4.0/.

Publisher's Note Springer Nature remains neutral with regard to jurisdictional claims in published maps and institutional affiliations.

The original article can be found online at https://doi.org/10.1007/ s00382-021-06032-z.

Chenghai Wang

wch@1zu.edu.cn

1 Key Laboratory of Climate Resource Development and Disaster Prevention of Gansu Province, Research and Development Centre of Earth System Model, College of Atmospheric Sciences, Lanzhou University, Lanzhou 730000, Gansu Province, China 